\title{
EVALUATION OF A SELF ADHESIVE FLOWABLE COMPOSITE; AN IN VITRO STUDY
}

\author{
Noha Hamdy* and Yasser F Gomaa**
}

\begin{abstract}
Objective: This study was to investigate and compare in-vitro shear bond strength of selfadhesive flowable composite and traditional adhesively bonded flowable composite.

Materials and methods: A total of 40 caries free extracted human premolars were collected for this test. They were divided into two groups, enamel group and dentin group with 20 teeth each. Teeth were placed in acrylic molds then enamel and dentin were flattened by silicon paper under coolant. Then each group was sub grouped into two sub groups, 10 teeth each according to the type of applied composite. Adhesives were applied and resin composite cylinders were prepared with Teflon tubes. The samples were tested for shear bond strength with a universal testing machine and stress at failure was calculated.
\end{abstract}

Results: self-adhesive flowable composite showed lower shear bond strength values with mean $(15 \pm 2.13)$ for enamel and $(16.38 \pm 2.44)$ for dentin than regular flowable composite with mean

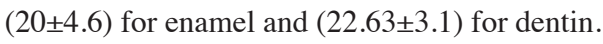

Conclusion: The mean shear bond strength of regular flowable composite and self-adhesive flowable composite values was higher with dentin than with enamel.

KEYWORDS: self-adhesive flowable composite, regular flowable composite and shear bond strength.

\section{INTRODUCTION}

Nowadays, durable esthetic tooth-colored restorative materials, particularly direct resin-based filling composites in combination with efficient enamel-dentin adhesives, play an important role in modern dentistry. The improvement of the dental adhesive technology has extensively influenced the clinical performance of modern dental restoratives $^{(1)}$.

Flowable composites are low-viscosity composite resins, making them more fluid than conventional composite resins. The percentage of inorganic filler is lower and some substances or rheological modifiers which are mainly intended

* Demonstrator in Biomaterials Department; Faculty of Dentistry; Fayoum University

** Associate Professor of Dental Biomaterials, Head of Biomaterials Department Faculty of Dentistry; Minia University 
to improve handling properties have been removed from their composition. Their main advantages are high wetability of the tooth surface, ensuring penetration into every irregularity; ability to form layers of minimum thickness, so improving or eliminating air inclusion or entrapment. ${ }^{(2)}$

Since the beginnings of adhesive dentistry, scientists and manufacturers have been continuously challenged by a general trend to simplify the clinical procedures. The most common approach was to shorten the adhesive system's application time and to reduce the number of steps. However, literature data shows that simplification does not always result in improved features and durability. ${ }^{(3)}$

Resin composites in common with the majority of dental materials; undergo deterioration and degradation in the intraoral environment. Being technique-sensitive materials, failure at the toothrestoration interface may also occur. ${ }^{(4)}$

The ideal dentin bonding agent should permanently bond the resin based restorative material to both dentin and enamel. The bond strength should be high enough to withstand polymerization shrinkage stresses and other intraoral factors such as variations in temperature and variation in mechanical loading. Hence, the achieved bond strength should therefore remain stable over the life time of the restoration. Furthermore it should be taken in consideration when to test the bond strength. It could be tested 24 hours after bonding as the patient will subject restoration with their bonds to a variety of mechanical and physical forces immediately after leaving the dental clinic. During the following months and years, chemical hydrolytic attack will also start playing an effective role. ${ }^{(5)}$

\section{This study aimed to:}

Investigate and compare in-vitro the shear bond strength of self adhering flowable composite and regular flowable composite.

\section{MATERIALS AND METHODS}

\section{Selection and Cleaning of Teeth for Shear bond Strength Test:}

A total of 40 extracted sound human maxillary and mandibular premolar teeth were collected following the guidelines of ethical parameters of the Faculty of dentistry and used in the current study. Cracked, fissured and teeth with similar defects were excluded. Each tooth was cleaned using manual scaler till all calculus was removed.

\begin{tabular}{|c|c|c|c|c|}
\hline $\begin{array}{c}\text { Materials } \\
\text { (brand name) }\end{array}$ & Description & Manufacturer & $\begin{array}{c}\text { Batch } \\
\text { Number }\end{array}$ & Composition \\
\hline $\begin{array}{l}\text { Flow IT }{ }^{\circledR} \text { ALC } \\
\text { Control Material } \\
\text { Non self adhesive } \\
\text { regular flowable } \\
\text { composite (RFCs) }\end{array}$ & $\begin{array}{l}\text { Light cured } \\
\text { flowable } \\
\text { composite } \\
\text { supplied in one } \\
\text { syringe, shade } \mathrm{A}_{2}\end{array}$ & $\begin{array}{c}\text { Pentron clinical, } \\
\text { USA }\end{array}$ & L4709529 & $\begin{array}{l}\text { Mixture of BISGMA, EBPADMA,TEGDMA, } \\
\text { silane, inorganic pigments, } \\
\text { bariumborosilicate glasses, with initiators, } \\
\text { stabilizers and UV absorber. Contains a small } \\
\text { amount of aluminum oxide. }\end{array}$ \\
\hline $\begin{array}{c}\text { Fusio }{ }^{\mathrm{TM}} \text { liquid } \\
\text { Test material self } \\
\text { adhesive flowable } \\
\text { composite(SACs) }\end{array}$ & $\begin{array}{l}\text { Light cured } \\
\text { flowable } \\
\text { composite } \\
\text { supplied in one } \\
\text { syringe, shade } \mathrm{A}_{2}\end{array}$ & $\begin{array}{c}\text { Pentron clinical, } \\
\text { USA }\end{array}$ & L4747163 & $\begin{array}{l}\text { GPDM, prepolymerized filler, } 1-\mu \mathrm{m} \text { barium } \\
\text { glass filler, nanosized colloidal silica, } \\
\text { nanosized Ytterbium fluoride }\end{array}$ \\
\hline
\end{tabular}


Then teeth were polished with a fluoride free polishing paste at low speed till all stains were removed. All teeth were then immersed in normal saline with $0.2 \%$ disinfectant Thymol solution at refrigerator not more than two months.

\section{2-Shear bond strength test}

\section{I- Grouping of teeth}

The cleaned premolar teeth were mounted through their roots in self cured acrylic resin blocks leaving the crown surface bared. These blocks were prepared in cylindrical molds $2 \mathrm{~cm}$ in height, $2 \mathrm{~cm}$ in diameter, and $0.5 \mathrm{~cm}$ in thickness painted with separating medium. The mounted teeth were randomly divided into two equal groups, 20 teeth each. The first group (E) received enamel preparation, while those of the second group (D) received dentin preparation.

\section{II- Preparation of teeth and application of materials}

Teeth of group E were ground using a diamond disc with low speed and coolant just to flatten the enamel, while teeth of group D were ground to remove coronal enamel and expose $1 \mathrm{~mm}$ of underlying dentinal surface. The groups $\mathrm{E}$ and $\mathrm{D}$ were then subdivided into two subgroups ten teeth each according to the type of applied composite. One subgroup of E and another one of D surfaces were treated with regular flowable composite (RFC) and denoted as $\mathrm{RFC}_{\mathrm{E}}$ and $\mathrm{RFC}_{\mathrm{D}}$ respectively. The remaining two subgroups were treated with selfadhesive composite (SAC) and denoted as $\mathrm{SAC}_{\mathrm{E}}$ and $\mathrm{SAC}_{\mathrm{D}}$ respectively.

In subgroups $\mathrm{RFC}_{\mathrm{E}}$ and $\mathrm{RFC}_{\mathrm{D}}$ the buccal surface of each tooth was etched with $37 \%$ phosphoric acid for $15 \mathrm{~s}$, thoroughly rinsed with water, and gently air dried for $5 \mathrm{~s}$. In order to ensure a standardized bonding area on the target surface, a part of an adhesive tape with a punched hole of $2.5 \mathrm{~mm}$ in diameter was placed on the prepared tooth then the bonding agent was then applied to the surface and dispersed with a faint stream of air till the mobile liquid film was no longer visible, and then light cured for 20 seconds with the light curing unit. Then a part of a rigid Teflon tube $2.5 \mathrm{~mm}$ in diameter and $3 \mathrm{~mm}$ in length was secured on the prepared surface of each tooth and then the tube filled with the resin RFC and light cured for 40 seconds from the unbounded surface, the tube was then removed and the composite received additional curing for 20 seconds.

The subgroups E2 and D2 received SAC which was applied directly on the prepared enamel and dentin after placing the adhesive tape with the punched hole and the rigid Teflon tube as previous and cured as previously mentioned. The light curing unit was checked for efficiency for each 10 specimens using visible light curing meter After Teflon tubes were removed the dimensions of composite cylinders were measured, then the specimens were tested for the bond strength.

\section{III- Shear Bond Strength Test}

The teeth of each sub-subgroup were tested for shear bond strength. The specimens were mounted in a custom fixture held in the lower grip of a Universal testing machine. A knife edged chisel $1 \mathrm{~mm}$ in cross section fixed on the upper grip of the machine was used to deliver the shearing force. The shearing load was applied to the composite tooth interface Fig.1 at a speed of $0.5 \mathrm{~mm} / \mathrm{min}$ with a preload stress of $5 \mathrm{~N}$ until separation of composite occurred. The shear bond strength $(\sigma)$ was calculated in Megapascals (Mpa) according to the following equation:

$$
\sigma=F / A M P a
$$

Where $\sigma$ is the shear bond strength $F$ is the maximum force in Newtons exerted on the specimen and $\mathrm{A}$ is the area of the bonded surface of the composite cylinder specimen in square millimeter 


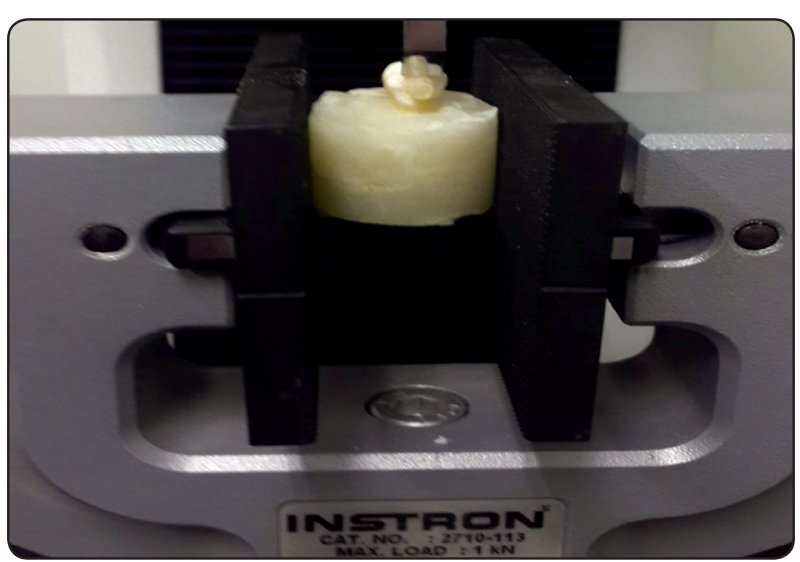

Fig. (1) Sample mounted in the Universal Testing Machine and the loading chisel at the tooth/restoration interface.

\section{RESULTS}

The study revealed that there is statistically significant difference with $\mathrm{p}$-value $<0.05$ between two study composites as regarding to shear bond strength enamel and dentin with high mean among Regular flowable composite as the following table illustrates

TABLE (1) Comparison of shear bond strength among different study composites.

\begin{tabular}{|l|c|c|c|c|c|c|}
\hline \multirow{2}{*}{ Variables } & \multicolumn{2}{|c|}{$\begin{array}{c}\text { Regular } \\
\text { flowable } \\
\text { composite }\end{array}$} & \multicolumn{2}{|c|}{$\begin{array}{c}\text { Self- } \\
\text { adhesive } \\
\text { flowable } \\
\text { composite }\end{array}$} & p-value & Sig. \\
\cline { 2 - 5 } & Mean & SD & Mean & SD & & \\
\hline $\begin{array}{l}\text { Shear bond } \\
\text { strength } \\
\text { enamel }\end{array}$ & $\mathbf{2 0}$ & 4.59 & 15 & 2.13 & $\mathbf{0 . 0 1}$ & $\mathbf{S}$ \\
\hline $\begin{array}{l}\text { Shear bond } \\
\text { strength } \\
\text { dentin }\end{array}$ & $\mathbf{2 2 . 6 3}$ & 3.06 & 16.38 & 2.44 & $<\mathbf{0 . 0 0 1}$ & HS \\
\hline
\end{tabular}

\section{DISCUSSION}

Shear bond strength test had been chosen because according to Sensi et al., $\mathbf{2 0 0 5}^{(\boldsymbol{( 6 )}}$, it is a simple evaluation procedure used to test the adhesion of dental adhesives. In vitro bond strength tests are

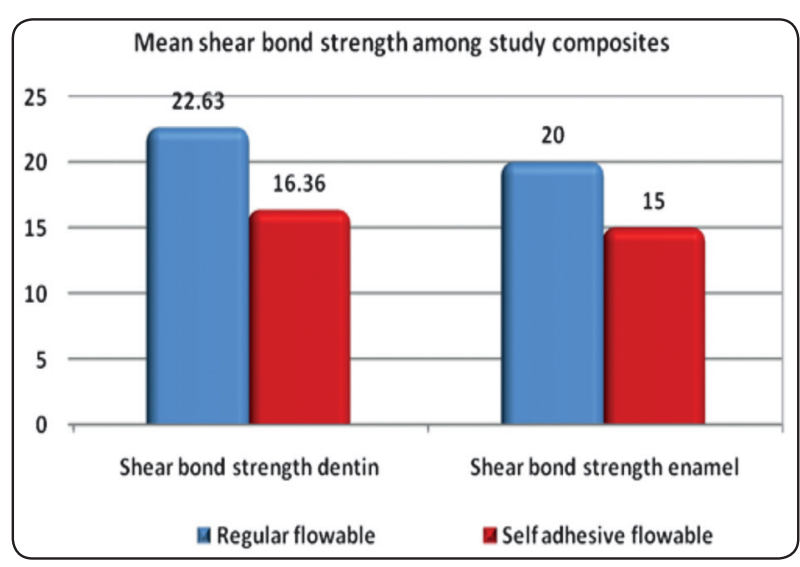

Fig. (2) Column chart shows mean shear bond strength among study composites

useful and essential for predicting the performance of new adhesive systems and possible correlation with clinical issues.

Bond strength studies are very important tools to evaluate the durability and efficiency of tooth colored restorations and their adhesives, as they reveal the life time of the restoration inside the patient mouth also Bond strength tests have been considered to provide a quantitative assessment of materials adhesion. Oliveira et al., 2009(7) and Vichi et al., $2013^{(8)}$.

Human teeth were used in this study according to Kumar et al., $\mathbf{2 0 0 5}^{(9)}$, as they provide the best model simulating the clinical situation in the lab studies and they decide the clinical effectiveness of tested materials also they were available for this study.

The selected teeth were preserved in refrigerator in normal saline with $0.2 \%$ Thymol solution for not more than two months to avoid the dehydration as normal saline doesn't affect the properties of enamel and dentin and Thymol inhibits microbial growth during the storage period without affecting the mechanical properties of teeth and to avoid any changes in the teeth tissues throughout the study. Rao, 2005 ${ }^{(10)}$. 
In this study self-adhesive flowable composite showed lower shear bond strength values than RFC to enamel and dentin; These results were in agreement with the results of Wajdowicz et al., 2011 $^{(11)}$ and Nuray et al, 2014 ${ }^{(12)}$.

The results were in contrast with Munoz and Campillo, 2010 ${ }^{(13)}$, who investigated the difference in bond strength between SAC and RFC and revealed that no statistical difference between them at 24 hours for either enamel or dentin. The difference in results might be attributed to specimen preparation as their specimens were sectioned longitudinally which was not done in this study and also their use of a universal testing machine at a test speed of $1 \mathrm{~mm} / \mathrm{min}$ and we used speed of $0.5 \mathrm{~mm} / \mathrm{min}$.

The difference in SBS in our study may be attributed to inability of self-adhesive composite to diffuse into the enamel and dentin layers as did the total etch adhesives, hence, forming weaker hybrid layer and shorter resin tags also inability to remove smear layer that gets incorporated into the bonded layers and plugs the opened dentinal tubules as explained by Shadman et al., 2012 ${ }^{(14)}$ and Watts and Silikas, $2005^{(15)}$.

According to Van Meerbeek et al., 2003 ${ }^{(16)}$, pre etching enamel significantly improves the bonding effectiveness, since phosphoric acid significantly enhances the surface energy of enamel and thus provides significantly more micro-retention. This may explain the lower shear bond strength values to enamel of SAC.

For self-adhesive flowable composite the wettability of the material should be considered. Proper wettability of an adhesive material onto a substrate enables a close adhesive substrate interaction, and this property could represent a drawback for the material's ability to wet self-etched collagen fibrils as claimed by Fu et al., 2013 ${ }^{(17)}$.

The lower SBS of SAC may be related to the viscosity of the material as explained by Poitevin et al., $2013^{(18)}$, who stated that to achieve selfadhesiveness, it is speculated that a relatively viscous (flowable) composite should contain a functional monomer that rather possesses an effective chemical bonding potential, as it cannot penetrate deeply.

\section{CONCLUSIONS}

The mean shear bond strength of regular flowable composite and self-adhesive flowable composite values was higher with dentin than with enamel.

\section{REFERENCES}

1. Cardoso M., Yoshida Y. and Van Meerbeek: B.: In Statements: diagnostics and therapy in dental medicine today and in future; Quintessenz: Berlin, 2009:25-43.

2. Olmez A, Oztas N19 and Bodur H.: The effect of flowable resin composite on microleakage and internal voids in class II composite restorations. Oper Dent, 2004; 29(19):713719 .

3. Meerbeek V, De Munk J, Yoshida Y, Inoue S, Vargas M, Vijay P, Van Landuyt K, Lamberechts P and Vanherle G: Adhesion to enamel and dentin: current status and future challenges. Oper Dent, 2003; 28(3):215-235.

4. Roulet JF, Wilson NHF and Fuzzi M.: Advances in Operative Dentistry: Contemporary clinical practice. Quintessence Publishing Co Inc, 2001; 13(3):141-144.

5. Brandt PD: Shear bond strength, microleakage and antibacterial properties of self etching bonding systems. Thesis for master degree, Faculty of Dentistry, University of Pretoria, South Africa, 2009: pg.22.

6. Senei LG, MarsonFC and Baratieri LN: Interfacial morphology of self- etching adhesive systems in dentin. Quintessence international, 2005; 38(2): 112-119.

7. Oliveira AC, Oshima HM, Mota EG and Grossi ML: Influence of chisel width on shear bond strength of composite to enamel. Rev. Odonto ciênc.2009; 24(1):19-21.

8. Vichi A, Margvelashvili M, Goracci C, Papacchini F and Ferrari M: Bonding and sealing ability of a new selfadhering flowable composite resin in class I restorations. Clin Oral Investig. , 2013; 17(6):1497-506. 
9. Kumar M, Sequeira PS, Peter S and Baht GK: Sterilization of extracted human teeth for educational use. Indian journal of medical microbiology, 2005; 23(4): 256-258.

10. Rao BT: the retentive strength of bonded amalgam restorations. Thesis submitted for the degree of master of sciences in restorative dentistry, Faculty of Dentistry, University of the Westren Cape, South Africa; 2005.

11. M., Means M. and Vandewalle K.: Enamel Shear Bond Strength of New Self-Adhesive Flowable Composite Resin, 2011.

12. Nuray Tuloglu, Emine Sen Tunc, Sezin Ozer and Sule Bayrak : Evaluation of the shear bond strength of conventional and self-adhering flowable resin composites. Pediatric dentistry, 2014:97-101.

13. Munoz-Viveros C. A. and Campillo-Funollet M.: Shear Bond Strength of Vertise Flow to Dentin and Enamel
Substrates. State University of New York at Buffalo, 2010; 32(5):85-105.

14. Shadman N, Ebrahimi SF, Abrishami A and Satt H: Shear bond strength of three adhesive systems to enamel and dentin of permanent teeth. Journal of Dental Medicine-Tehran University of Medical Sciences, 2012; 25(3):202210.

15. Watts D and Silikas N: In Situ photo-polymerisation and polymerisation shrinkage phenomena. Dental hard tissues and bonding, $1^{\text {st }}$ Edition, New York.

16. Van Meerbeek B, De Munck J, Yoshida Y, Inoue S, Vargas $\mathrm{M}$ and Vijay P.: Adhesion to enamel and dentin: current status and future challenges. Oper Dent., 2003; 28:215-35.

17. Fu J, Kakuda S, Pan F, Hoshika S, Ting S and Fukuoka A.: Bonding performance of a newly developed step-less allin-one system on dentin. Dent Mater. 2013; 32(2):203-11 Springer Publications, 2005; Pg123-49. 